\title{
Connectivities with shellfish farms and channel rivers are associated with mortality risk in oysters
}

\author{
Aline Gangnery ${ }^{1, * * *}$, Julien Normand ${ }^{1, * *}$, Cyrielle Duval $^{1}$, Philippe Cugier ${ }^{2}$, \\ Karine Grangeré ${ }^{3}$, Bruno Petton ${ }^{4}$, Sébastien Petton ${ }^{4}$, Francis Orvain ${ }^{3}$, Fabrice Pernet ${ }^{5}$ \\ ${ }^{1}$ Ifremer, Laboratoire Environnement Ressources de Normandie, Avenue du Général de Gaulle, 14520 Port en Bessin, France \\ ${ }^{2}$ Ifremer, Laboratoire d'Ecologie Benthique Côtière, Technopole Brest-Iroise, 29280 Plouzané, France \\ ${ }^{3}$ Université de Caen Basse-Normandie, UMR BOREA, Esplanade de la Paix, BP 5186, 14032 Caen cedex, France \\ ${ }^{4}$ Ifremer, UMR 6539 LEMAR, 11 presqu'île du vivier, 29840 Argenton en Landunvez, France \\ ${ }^{5}$ Ifremer, UMR 6539 LEMAR, Technopole Brest-Iroise, 29280 Plouzané, France
}

\begin{abstract}
Oyster diseases have major consequences on fisheries and aquaculture. In France, young Pacific oysters Crassostrea gigas are severely hit by the ostreid herpesvirus, whereas adults suffer mortalities presumably caused by pathogenic bacteria. Here we investigated the origin and spread of mortalities that affect both young and adult oysters, and we identified and compared their risk factors. Mortality was monitored in 2 age classes of oysters deployed in early spring at 39 sites spread over a $37 \mathrm{~km}^{2}$ surface area inside and outside of shellfish farms. Environmental data obtained from numerical modelling were used to investigate risk factors. Mortality of young oysters associated with ostreid herpesvirus occurred in the oyster farming area. Hydrodynamic connectivity with oyster farms was associated with higher mortality risk, whereas chlorophyll $a$ concentration was associated with a lower risk. Adult oysters experienced 2 mortality events that were associated with different risk factors. The first event, which occurred after deployment and was probably caused by endogenous pathogens, was mainly associated with connectivity to channel rivers and salinity. The second mortality event observed at the end of the summer was mainly associated with connectivity to oyster farms, suggesting pathogen transmission. The risk factors involved in young and adult oyster mortalities were partly different, reflecting distinct origins. Connectivity with oyster farms is a mortality risk factor for both young and adult oysters; thus, disease management strategies that focus on oyster farming areas will impact overall disease risk.
\end{abstract}

KEY WORDS: Aquaculture - Bivalve · Disease · Epidemiology and health · Ecological modelling · Hydrodynamic connectivity

\section{INTRODUCTION}

Mortality outbreaks in Pacific oyster Crassostrea gigas associated with diseases of complex aetiology have increased during the last $10 \mathrm{yr}$ worldwide (Barbosa Solomieu et al. 2015, EFSA AHAW Panel 2015). In France, young oysters (less than 1 yr old) have been severely hit by a microvariant of the ostreid herpesvirus 1 (OsHV-1 $\mu$ Var) since 2008, whereas adults have been facing the (re)emergence of the bacteria Vibrio aestuarianus since 2012 (Azéma et al. 2017). The economic costs and vulnerability of oyster farming associated with increased mortalities have promoted

${ }^{*}$ Corresponding author: aline.gangnery@ifremer.fr

** These authors contributed equally to this work investigation of disease risk factors to improve farm management.

A great deal of work has been done on OsHV-1 disease risk (Pernet et al. 2016). For instance, OsHV-1 disease outbreaks were associated with environmental factors, such as seawater temperature (Pernet et al. 2012, 2015, Paul-Pont et al. 2013, Petton et al. 2013, Renault et al. 2014, de Kantzow et al. 2016, Delisle et al. 2018), salinity (Fuhrmann et al. 2016), pH (Fuhrmann et al. 2019), microbial communities (Lemire et al. 2015, Petton et al. 2015b, de Lorgeril et al. 2018), proximity to oyster farms (Pernet et al. 2012, 2014a, Pernet 2018) and hydrodynamic regime

() The authors 2019. Open Access under Creative Commons by Attribution Licence. Use, distribution and reproduction are unrestricted. Authors and original publication must be credited. 
(Pernet et al. 2012, Petton et al. 2015a), as well as with host factors such as age and size (Dégremont 2013, Paul-Pont et al. 2013, Petton et al. 2015a, Hick et al. 2018), genetic background (Dégremont 2011, Dégremont et al. 2015), life-history traits and physiological status of oysters (Pernet et al. 2014b, Tamayo et al. 2014).

In comparison, mortality risk factors for adult oysters are far from being clear. Pathogens, environment and physiological status of the host all interact in their effects on adult oyster mortality (Samain \& McCombie 2008). More specifically, in temperate estuarine ecosystems, mortality of adult oysters was associated with the temporal increase in seawater temperature during the warm season, freshwater outflow from rivers and subsequent drop in salinity, and excessive increase in nutrient and phytoplankton concentrations, which induce metabolic disorders associated with reproductive effort and stress (Delaporte et al. 2006, Royer et al. 2007, Soletchnik et al. 2007, Bushek et al. 2012, Go et al. 2017). This agrees with the fact that mortality events recorded along the Atlantic coast of France between 1986 and 2015 usually occur several months after winters dominated by the occurrence of positive North Atlantic oscillation (NAO+) atmospheric regimes of circulation (Thomas et al. 2018). The NAO+ is characterized by positive anomalies in air temperature and rainfall and locally translates into higher sea surface temperature, higher river flow and lower salinity and higher chlorophyll concentration due to the intrusion of nutrient-rich riverine waters (Thomas et al. 2018). Recent mortalities of adult oysters have often been associated with V. aestuarianus (EFSA AHAW Panel 2015, Goudenège et al. 2015, Parizadeh et al. 2018). Although growth, life stage and persistence of $V$. aestuarianus are mostly influenced by temperature and less by salinity (Vezzulli et al. 2015), there is no clear evidence that these parameters influence infection and mortality risk of the host (Barbosa Solomieu et al. 2015, EFSA AHAW Panel 2015, Parizadeh et al. 2018).

Recently, Pernet et al. (2018) investigated how the marine environment drives the spread of OsHV-1 by using a broad-scale spatial epidemiology framework. Spatial epidemiology involves the description and analysis of geographical variations in disease to identify risk factors that could explain these patterns (Elliott \& Wartenberg 2004, Ostfeld et al. 2005). In their study, Pernet et al. (2018) collected environmental and oyster health data along an inshore-offshore gradient during an epizootic event and investigated risk factors. They showed that mortality began in the intertidal farming area, spread $2 \mathrm{~km}$ away from the farming areas, and oysters at almost all sites were subclinically infected by the virus. Increasing food quantity and quality, growth rate and energy reserves of oysters were associated with a lower risk of mortality offshore, whereas increasing turbidity and terrestrial inputs were associated with a higher risk of mortality.

Our objective here was (1) to investigate the origin and spread of mortalities that currently affect both young and adult oysters and (2) to identify and compare their environmental risk factors. We applied a spatial epidemiology framework similar to that of Pernet et al. (2018) in an estuarine ecosystem (Baie des Veys, Normandy, France). The originality of our study site is that (1) it is exposed to massive freshwater inputs coming from 2 channels that were previously associated with summer mortalities of adult oysters (Samain \& McCombie 2008, Grangeré et al. 2009), (2) it is dedicated to both oyster and mussel farming, (3) annual mortality of young oysters is among the lowest in France, while it is the highest for adults (Fleury et al. 2015), and (4) it is free of wild $C$. gigas, so there is no possible transmission of pathogens between wild and cultivated oyster stocks.

Mortality was monitored in 2 age classes of sentinel oysters (young vs. adult) deployed at 39 sites spread over a $37 \mathrm{~km}^{2}$ surface area inside and outside of the shellfish farms. High-frequency data of seawater temperature, salinity, phytoplankton concentration and hydrodynamic connectivity to oyster farms and to the river channels were obtained from a 3D hydrodynamic model coupled with a biogeochemical model and further used to investigate mortality risk factors.

\section{MATERIALS AND METHODS}

\subsection{Study site}

The Baie des Veys (BdV) is an estuarine ecosystem located on the French coast of the English Channel (Fig. 1 and see Ubertini et al. 2012). Briefly, BdV is characterized by a macrotidal regime reaching a maximum of $7 \mathrm{~m}$ during spring tides and an intertidal area covering $37 \mathrm{~km}^{2}$. The mean depth is ca. $4 \mathrm{~m}$, and current velocity can reach $3 \mathrm{~m} \mathrm{~s}^{-1}$ during flood tides and $1.5 \mathrm{~m} \mathrm{~s}^{-1}$ during ebb tides. Four rivers flow into the bay through 2 channels (Isigny, collecting the Vire and Aure Rivers, and Carentan, collecting the Douve and Taute Rivers), bringing massive freshwater inputs. Total mean discharge (for the 4 rivers) was $43.3 \mathrm{~m}^{3} \mathrm{~s}^{-1}$ for the period 2000-2006 (Passy et al. 2016) and $38.7 \mathrm{~m}^{3} \mathrm{~s}^{-1}$ for the year 2014 (data available 


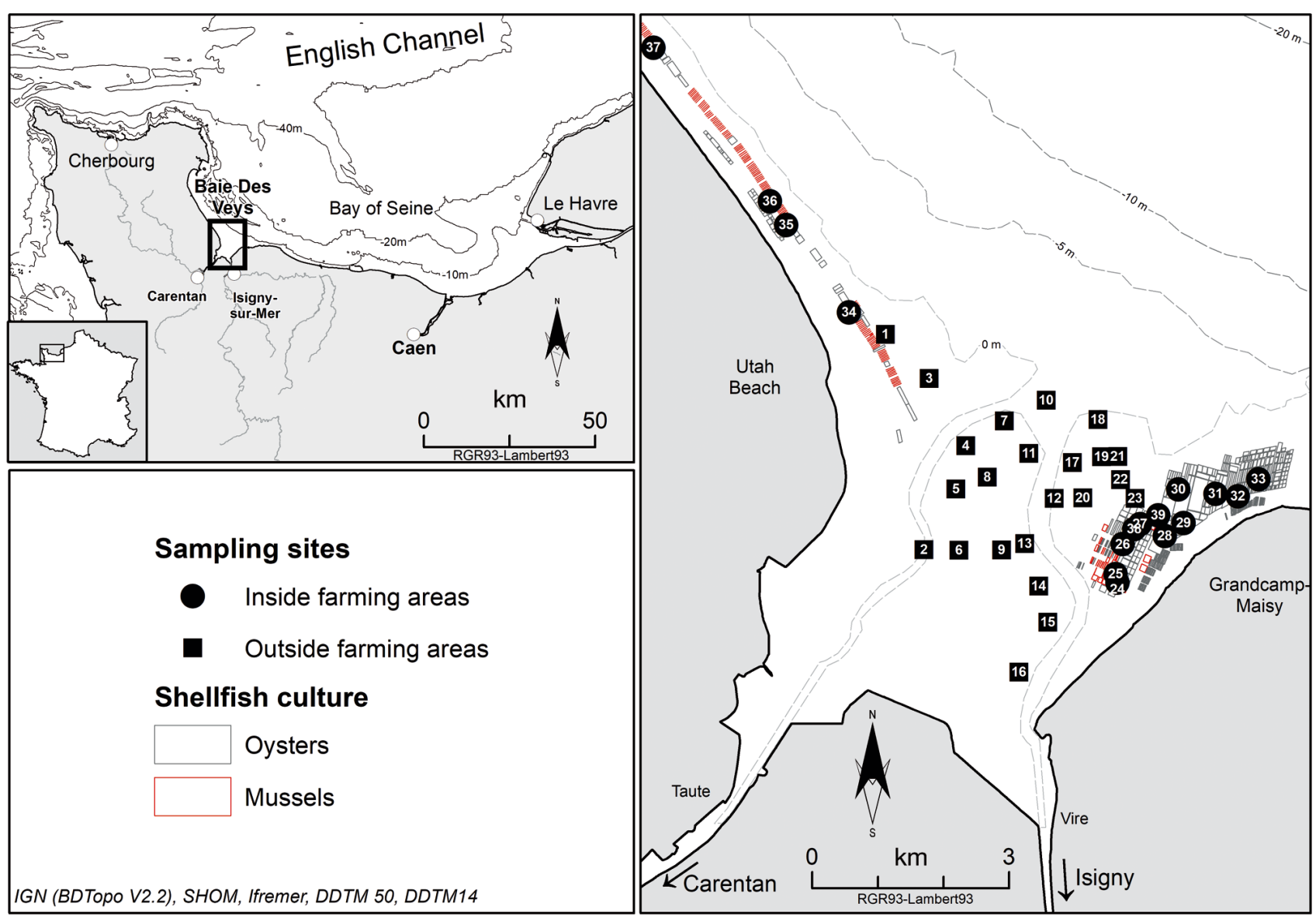

Fig. 1. Baie des Veys. Young ( $<1$ yr) and adult Pacific oysters were deployed at 23 sites located outside shellfish farming areas (Sites 1-23, black squares) and at 16 sites located within 2 bivalve farming areas (black circles), namely Grandcamp (Sites 24-33, 38 and 39) and Utah Beach (Sites 34-37)

at www.hydro.eaufrance.fr/). The BdV supports an important shellfish farming activity concentrated in 2 areas: Grandcamp and Utah Beach (Fig. 1). Grandcamp is mainly dedicated to Pacific oysters Crassostrea gigas, whereas Utah Beach equally supports mussels Mytilus edulis and oysters (Gangnery et al. 2015). There is no natural oyster recruitment in the $\mathrm{BdV}$, so that the stock of oysters consists only of farmed animals. In 2014, mean daily seawater temperature and salinity varied between 7.9 and $21.3^{\circ} \mathrm{C}$ and 25.9 and 34.6, respectively, in the Grandcamp farming area (https://wwz.ifremer.fr/observatoire conchylicole/).

\subsection{Sentinel oysters}

Two age classes of oysters, i.e. young $(<1 \mathrm{yr})$ and adult oysters, were used as sentinels. The young oysters were produced at the Ifremer experimental facilities of Argenton in July 2013 according to a standard procedure developed by Petton et al. (2015a). They were descendants of a pool of genitors produced under controlled conditions to minimize the influence of genetic and environmental parameters that could affect host sensitivity to the disease (Petton et al. 2015a, Le Roux et al. 2016). Before the experiment, a subsample ( $\mathrm{n}=150$ oysters) of the young population was exposed to a thermal elevation from 12 to $21^{\circ} \mathrm{C}$ for $1 \mathrm{mo}$ in cohabitation with new specificpathogen-free (SPF) oysters (Le Roux et al. 2016) to reveal both disease expression and pathogen transmission (Petton et al. 2015a). There was no oyster mortality, OsHV-1 DNA was not detected by qPCR

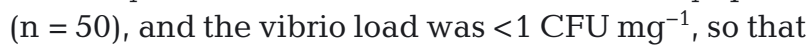
the young oysters could be considered SPF. At the beginning of the experiment, these SPF oysters were 8 mo old, with a mean shell length of $18.2 \mathrm{~mm}$ and a mean body mass of $0.75 \mathrm{~g}$.

Adult SPF oysters were not available. Therefore, the adult oysters were sourced from a natural spatfall collection from Marennes-Oléron (France) in summer 2010 grown in BdV since 2011. Similarly to young oysters, the adults were exposed to a thermal 
elevation at $21^{\circ} \mathrm{C}$ in cohabitation with SPF oysters. The adults exhibited $38 \%$ mortality after $30 \mathrm{~d}$, suggesting that they vectored pathogenic bacteria because (1) the cohabiting SPF oysters also exhibited mortalities, (2) there was an outbreak of Vibrio in both adults and cohabiting SPF, and (3) OsHV-1 DNA was not detected in oysters (Petton et al. 2015b, Parizadeh et al. 2018). At the beginning of the experiment, the adult oysters were 42 mo old, with mean shell length $75.7 \mathrm{~mm}$ and mean body mass $33.9 \mathrm{~g}$.

\subsection{Experimental design and sampling}

Young and adult oysters were placed at 39 sites well interspersed within the bay on 14-18 April 2014, 2 mo before the start of the annual OsHV-1 outbreak (seawater temperature was around $11^{\circ} \mathrm{C}$ ), and were left until 9 September (young) or 16 October (adults) (Fig. 1). Sixteen sites (Sites 24-39) were in the intertidal farming areas while the other sites were offshore (Sites 1-23). At each site, young oysters were placed into 13 small mesh bags $(22 \times 20 \times 2 \mathrm{~cm}, 6 \mathrm{~mm}$ mesh) containing 35 individual oysters, and the small bags were gathered in 1 large mesh bag $(90 \times 45 \times$ $8 \mathrm{~cm}, 10 \mathrm{~mm}$ mesh, Pernet et al. 2018), whereas adult oysters were directly placed in 1 large mesh bag containing 100 individuals. In the intertidal farming area, the oyster bags were attached to $70 \mathrm{~cm}$ high iron tables placed at a depth ranging from -2.17 to $0.49 \mathrm{~m}$ around chart datum. For the sites in the offshore area, oyster bags were suspended from surface buoys to a depth of $2 \mathrm{~m}$ (Pernet et al. 2018). Therefore, the oyster bags were kept at $2 \mathrm{~m}$ depth as long as the water level was high. When the tide receded and the water level was $<2 \mathrm{~m}$, the oysters remained on the bottom.

Each site was visited 9 times (12-15 May, 13-16 and 26-30 June, 12-18 and 27-29 July, 11-14 and 25-27 August, 9-12 September and 16 October) during spring tides to measure oyster survival and collect samples for pathogen detection analyses. The intertidal farming sites were visited on foot at low tide, whereas the offshore sites were visited by boat. The oyster bags at Sites 14 and 15 (young and adult) and Sites 10, 12 and 16 (adults only) were lost during the experiment.

For young oysters, 2 small mesh bags ( $\mathrm{n}=70$ individuals) were collected on each date and brought back to the laboratory to count dead and live individuals and to collect samples. On 2 occasions, counting and sampling were done directly in the field. For adult oysters, live and dead animals were directly counted in the field, and the dead ones were removed from the bag.
On 13-16 June, when the mortality outbreak among young oysters began, 10 animals were collected at each of 12 sites located in the farming areas of Grandcamp (Sites 24, 28, 29, 31, 32, 39) and Utah Beach (Sites 34 and 35) and outside the farming areas (Sites 5, 10, 16, 22) for individual OsHV-1 DNA detection. On 9-12 September, when young oyster mortalities had stabilized, 2 pools of 5 individuals were collected at 6 of the 12 previously selected sites (Sites 5, $16,22,24,35,39)$ for OsHV-1 detection analyses. On 16 October, 6 adult oysters were collected at 18 sites (Sites 2, 3, 5, 9, 10, 18, 19, 20, 22, 24, 26, 28, 32, 34, 35, $37,38,39)$, where the number of living individuals was sufficient to screen for Vibrio aestuarianus DNA. Detection and quantification of pathogen DNA were carried out by the Pole d'Analyses et de Recherche de Normandie (LABEO, Saint-Lô, France) using standard real-time PCR protocols (Martenot et al. 2010, Saulnier et al. 2017). The OsHV-1 load was expressed in viral genome units (GU) per $50 \mathrm{mg}$ of oyster tissue (wet mass). One GU corresponded to 1 viral particle (Martenot et al. 2010). For V. aestuarianus, very few animals were positive so that we only report the number of infected oysters.

\subsection{Environmental parameters}

In a previous spatial epidemiology study, environmental parameters (temperature, salinity, fluorescence, turbidity and oxygen) were obtained from occasional measurements at the vicinity of the oyster bags using a multiparameter probe (Pernet et al. 2018). Here we proceeded differently because the frequency of acquisition of the environmental data was low, the residence time of seawater was short, and it was not possible to obtain environmental data in the intertidal zone at low tide. Instead we used a validated 3D hydrodynamic Model for Applications at Regional Scale (MARS-3D, Lazure \& Dumas 2008) coupled with a biogeochemical model (ECOMARS3D; fully described by Ménesguen et al. 2019) to generate data at a high frequency (every hour) for seawater temperature, salinity, chlorophyll a (chl a) concentration (derived from phytoplankton) and hydrodynamic connectivity to oyster farms and to the mouths of the channel rivers at the 39 sites.

Briefly, the model extent is $49.34^{\circ} / 49.52^{\circ} \mathrm{N}$ and $1.30^{\circ} / 0.85^{\circ} \mathrm{W}$. The computational grid is regular with a horizontal spatial resolution of $200 \mathrm{~m}$ and a vertical discretization of 10 sigma layers. The biogeochemical model is a 'nutrients, phytoplankton, zooplankton and detritus' (NPZD) model that was previously de- 
veloped for the BdV (Grangeré et al. 2010). Mechanical forcing was provided by the barotropic sealevel oscillation at the marine boundaries coming from a $500 \mathrm{~m}$ resolution model covering the Bay of Seine (Passy et al. 2016). Data for wind and atmospheric pressure at the sea surface came from the Arpege system of Météo-France with a $6 \mathrm{~h}$ time resolution. River forcing was based on measurements carried out by the Seine-Normandy River Basin Agency in the 4 tributaries in 2014: daily discharges and monthly concentrations of nutrients (ammonium, nitrates, phosphates, silicates), suspended matter and temperature. A model covering the English Channel and the Bay of Biscay at a spatial resolution of $4 \mathrm{~km}$ provided the marine boundary conditions: salinity, temperature, nutrient concentrations (ammonium, nitrates, phosphates, silicates), suspended matter concentration, phytoplankton (diatoms and dinoflagellates) and zooplankton with a $4 \mathrm{~d}$ time resolution (https://marc.ifremer.fr/). The model was calibrated and then validated against the measured data (Supplement 1 at www.int-res.com/ articles/suppl/q011p493_supp.pdf; URL applies for all supplements, supplementary figures and tables). Output values were from the bottom layer for the sites in the rearing areas and from the surface layer for the others. Spatial and temporal variations in temperature, salinity and chl a concentration issued from the model are available in the data repository at https:// doi.org/10.17882/62354.

We used a connectivity-based index that reflected the potential of particles to move from (1) the channel rivers (2 source sites, Carentan and Isigny) or (2) the oyster farming areas (6 source sites for Grandcamp and 2 source sites for Utah Beach; Fig. S3 in Supplement 2) to the sampling sites $(\mathrm{n}=39$ destination sites). Virtual particles were released as Eulerian tracers from each source site at a flow of 1 unit s ${ }^{-1} \mathrm{~m}^{-3}$ during at least spring-neap tide cycle. Connectivity between a source and a sampling site was evaluated by the standardized median amount of tracer present at the sampling site during the simulation period. For farming areas, tracer quantities from all source sites were firstly averaged before calculating the median over time. Connectivity of the sampling sites with the channel rivers was estimated during the winter (between 29 January and 12 February, Table S1 in Supplement 2). The underlying hypothesis is that freshwater runoff during the winter is associated with summer mortality of adults (Samain \& McCombie 2008, Grangeré et al. 2009). In contrast, connectivity with the farming areas was estimated during 2 periods preceding mortality events, i.e. during the spring for young and adult oysters (8 to 19 May) and during the summer for adults only (1 to 15 August). The hypothesis is that mortalities are due to pathogens originating from the farming areas (Pernet et al. 2012 , 2014b, 2018). For a comparison, and because oysters were not deployed at the 39 sites in February, connectivity with river channels was also estimated for May and August. Values of connectivity are reported in the data repository and are mapped in Fig. S4 in Supplement 2.

\subsection{Statistics}

Cumulative and daily mortalities were calculated for young and adult oysters for each site. For young oysters, cumulative mortalities were fitted to a sigmoid regression model to smooth the variations associated with changes in sampling bags, and simulated values were then used instead of observations (Supplement 3). Associations between cumulative mortality of oysters and environmental variables were tested using stepwise (forward) generalized linear models (logit link). Error distributions were binomial for adults and quasi-binomial for young oysters. For young oysters, smoothed mortality values were used instead of observations (Faraway 2016). For each model, environmental variables were then selected based on Akaike's information criterion (AIC) values obtained from univariate models for adults, or using a likelihood ratio test to compare the residual deviance between the nested models for young oysters. The environmental variables tested in the models were the connectivity index (square root transformed) with farming areas and river channels, temperature and salinity (median of daily median) and chl a (mean of daily mean). Median or mean values were chosen to maximize spatial variability and were calculated for the whole study period for young and for Periods 1 and 2 for adult oysters (see Section 3.1 for the definition of the periods). All data are provided in the data repository.

Spatial structure of observed mortality was analysed though semi-variograms allowing quantification of the spatial dependency and its partitioning among distance classes (Legendre \& Legendre 1998; Supplement 4). Statistical models, e.g. spherical, exponential, Gaussian and Bessel, were fitted to semivariograms, and the best model was selected by cross validation as described by McBratney \& Webster (1986). Briefly, each value of the 39 sites from which the semi-variogram was computed was removed from the dataset, and the value at that point was re-estimated from the remainder by kriging. Finally, cokriging was used for predicting mortality and map- 


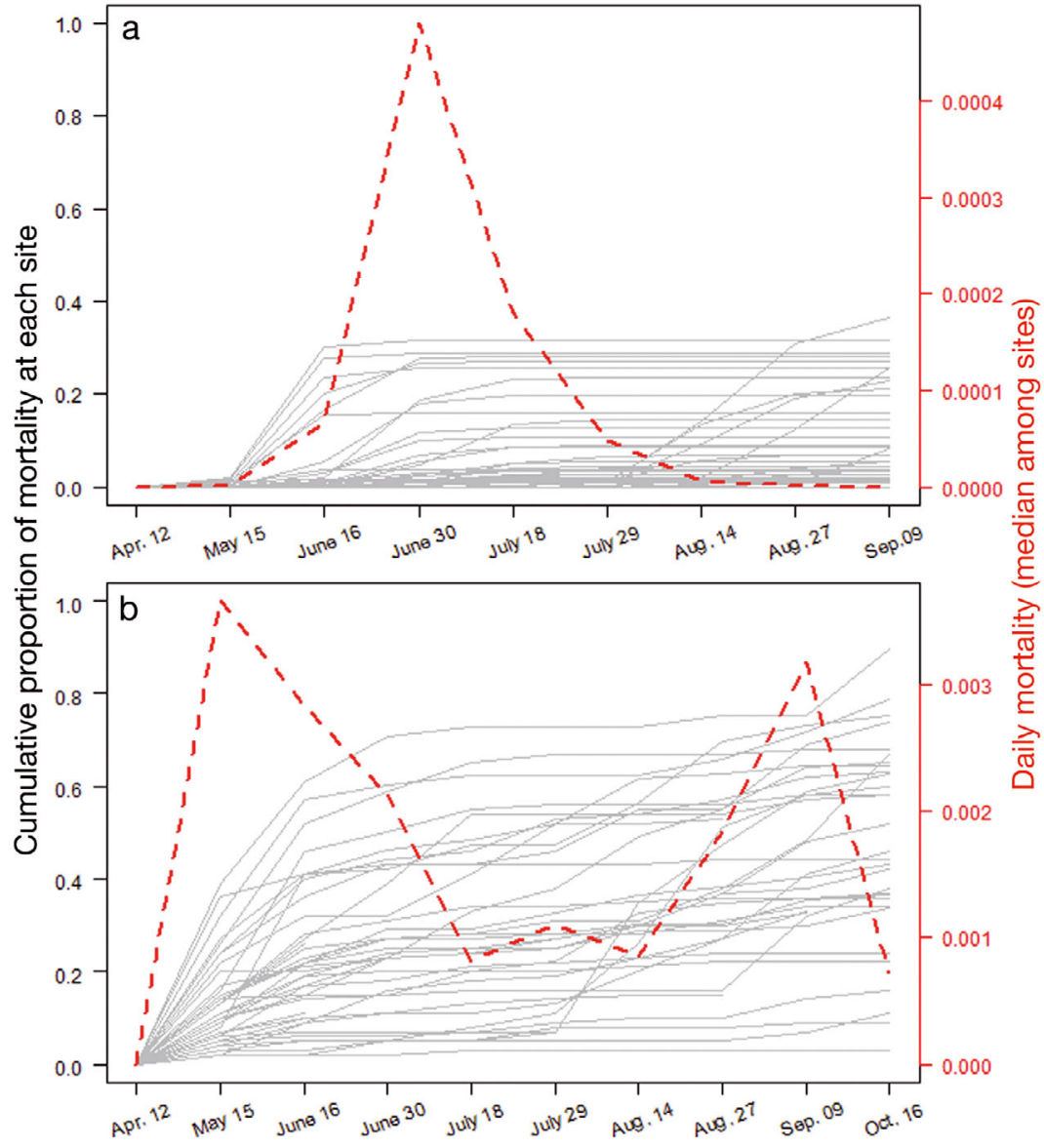

Fig. 2. Cumulative mortality as a function of time for (a) young and (b) adult Pacific oysters for each site (grey solid lines) and median daily mortality among all sites (red dashed lines). For young oysters, smoothed data are plotted

mortality events: the first began just after deployment in the field in May and lasted until July (Period 1), and the second occurred between mid-July and October (Period 2, Fig. 2). We therefore analysed cumulative mortality in September for young oysters and at the end of Periods 1 and 2 for the adults.

Mortality of young oysters was concentrated at sites located within the shellfish farming area of Grandcamp or nearby (Sites 21-23) and varied between 2 and $37 \%$ (Site 22; Fig. 3a). Mortalities were also recorded outside the shellfish area in the center of the Bay (Site 5; 23\% mortality) and at the northwesternmost site (37; 16\% mortality). Everywhere else, young oyster mortalities were below $15 \%$. The range of the best fitted semi-variogram to the mortality data was $1691 \mathrm{~m}$ (Table 1; Fig. S7 in Supplement 4), indicating that sites farther apart were not spatially autocorrelated.

Mortality of adult oysters was lowest in the farming area of Utah Beach (Fig. 3b). Otherwise, there was no clear spatial pattern of adult mortality. However, the sep-

ping. Co-variables were selected by the logistic regression procedure and improved our mortality predictions. Direct and cross semi-variograms were first constructed before fitting a model of co-regionalization. Parameters of simple semi-variogram models of mortality (type of the model, nugget, partial sill and range) were used as initial values when fitting coregionalization models. A cross-validation procedure was again applied to estimate the accuracy of our predictions.

These analyses were performed in $\mathrm{R}$ software $(\mathrm{R}$ Core Team 2018) and maps were made in ArcGIS software (ESRI, www.esri.com).

\section{RESULTS}

\subsection{Oyster mortality}

Young oysters exhibited a single mortality event between June and July, whereas adults showed 2 arate analysis of mortality events by period allowed us to identify spatial patterns, although the first mortality event was less clear than the second. During the first period, mortalities were high in the southwestern part of the bay (the average of Sites 2, 5, 6, 8 and 13 was $62 \%$ ), medium in the shellfish farming area of Grandcamp (Sites 24-33, 38 and 39) and almost nil at Sites 7 , 9,14 and 18. The range of the best-fitted semivariogram to the mortality data was $2340 \mathrm{~m}$ (Table 1; Fig. S8 in Supplement 4).

During the second period, mortalities of adult oysters were concentrated in the shellfish farming area of Grandcamp and nearby. The average mortality was $35 \%$, and the maximum was $61 \%$ (Site 25, Fig. 3d). Mortalities were observed outside the farming area at Sites $2(48 \%)$ and 13 $(40 \%)$. Everywhere else, mortalities were below $15 \%$. The range value of the best fitted semi-variogram model was $2922 \mathrm{~m}$ (Table 1; Fig. S9 in Supplement 4). 

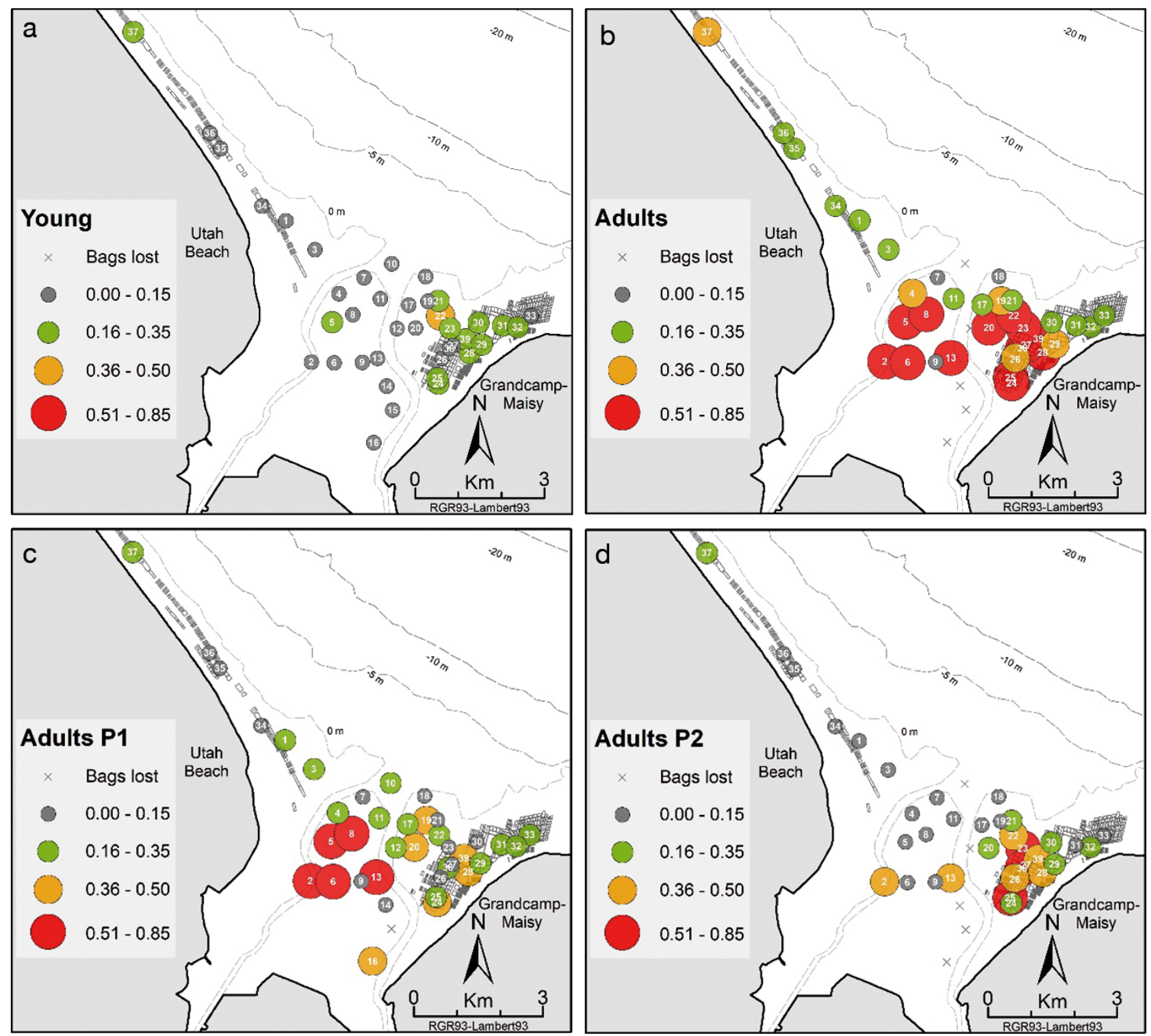

Fig. 3. Cumulative mortality during the entire study period for (a) young and (b) adult Pacific oysters, and for adults from (c) May to mid-July (Period 1) and (d) mid-July to October (Period 2). For young oysters, smoothed data are plotted

\subsection{Pathogen detection}

On 13-16 June, OsHV-1 DNA was almost systematically detected in young oysters held in the farming area of Grandcamp where mortalities were occurring (59 of 60 oysters sampled at 6 sites were positive, Table 2). Outside the farming area, OsHV1 DNA was occasionally detected, reflecting that mortalities were much rarer and more isolated (11 of 40 oysters were positive in 3 of 4 sites). In the farming area of Utah Beach, OsHV-1 DNA was not detected in young oysters while no mortality was recorded. Therefore, the detection of OsHV-1 DNA was associated with mortalities of young oysters (ANOVA $\chi^{2}, p<0.001$, Supplement 5). On 9-12 September, after the mortality event, OsHV-1 DNA was detected in young oysters sampled in the Grandcamp farming area and outside at a much lower level than in June, but still not in the animals collected in the farming area of Utah Beach.

At the end of the experiment in October, DNA of Vibrio aestuarianus was detected in tissues of adult oysters at 2 of 18 sites in the farming area of Grandcamp in only 1 of 6 oysters at each site (Table 2). 
Table 1. Coregionalization models of Pacific oyster mortality by ordinary co-kriging with their parameter values and cross-validation results. Period 1: May to mid-July, Period 2: mid-July to October

\begin{tabular}{|lcccccccc|}
\hline & $\begin{array}{l}\text { Variogram } \\
\text { model }\end{array}$ & & Nugget & $\begin{array}{c}\text { Partial Range } \\
\text { sill }\end{array}$ & $\begin{array}{c}\text { R2 (cross- } \\
\text { validation) }\end{array}$ & $\begin{array}{c}\text { Mean } \\
\text { error }\end{array}$ & RMSE \\
\hline Young & Exponential & 0.011 & 0.013 & 1691 & 0.4 & $-2.6 \times 10^{-4}$ & 0.08 \\
Adults Period 1 & $\begin{array}{c}\text { Bessel } \\
\text { Adults Period 2 }\end{array}$ & 0.023 & 0.041 & 2340 & 0.3 & $-4.1 \times 10^{-5}$ & 0.16 \\
& Spherical & 0.016 & 0.035 & 2922 & 0.62 & $-4.8 \times 10^{-3}$ & 0.12 \\
\hline
\end{tabular}

\subsection{Association between environmental variables and mortality risk}

Connectivity to the Grandcamp farming area was strongly associated with a higher risk of mortality in young oysters. To a lower extent, chl a concentration was associated with a lower mortality risk (Table 3). Connectivity to the Utah Beach farming area and channel rivers (February and May), seawater temperature and salinity were not associated with mortality risk in young oysters. Connectivity to the Grandcamp farming area and chl a concentration were selected by the stepwise procedure in the multiple covariates logistic regression model (Table 3 ).

During the first period, connectivity to channel rivers (both Carentan and Isigny), temperature and chl a concentration were associated with a higher risk of mortality in adults, whereas increasing salinity was associated with a lower mortality risk. Connectivity to Grandcamp and Utah Beach farming areas was not associated with mortality risk in adults during this period. Connectivity to a channel river (Carentan only) and salinity were included in the final regression model (Table 3).

During the second period, connectivity to the Grandcamp farming area, the Isigny channel and, to a lower extent, the Carentan channel in August were associated with a higher risk of mortality in adults. In contrast, connectivity to the Carentan channel in February and the Utah Beach farming area, salinity, chl a concentration and seawater temperature were associated with a lower mortality risk. All variables except connectivity to the Isigny and Carentan channels in August were retained in the final regression model (Table 3). However, connectivity to the farming areas (Grandcamp and Utah
Beach) and salinity were the strongest associated variables.

A map of predicted young oyster mortality was produced by co-kriging using connectivity to the Grandcamp farming area and chl $a$ as input variables (Fig. 4). The fit between prediction and observation was moderate but highly significant $\left(\mathrm{R}^{2}=0.40\right.$, Table 1$)$. Predictions reflect observations (Fig. 3a), as (1) a mortality outbreak occurred in the farming area of Grandcamp, (2) cumulative mortality reached $30 \%$ at many sites, (3) no mortality occurred in the central part of the bay, and (4) low mortality was observed at 1 site in the northwestern part of the bay. Finally, the model predicted low mortality in the southwestern part of the bay, but this prediction was associated with high standard error (data not shown), indicating poor kriging reliability in this area due to lack of observations.

Table 2. Pathogen detection in young and adult sentinel Pacific oysters. Prevalence indicates the number of positive individuals out of the total analysed. OsHV-1 load is expressed in viral genome units (GU) per $50 \mathrm{mg}$ of oyster tissue (wet mass); 1 GU corresponds to 1 viral particle (Martenot et al. 2010). Details of the sampling protocol are given in Section 2.3. -: no analysis

\begin{tabular}{|c|c|c|c|c|}
\hline \multirow[t]{4}{*}{ Site } & \multicolumn{3}{|c|}{ - Young } & \multirow{4}{*}{$\begin{array}{c}\text { Adults } \\
16 \text { October } \\
\text { Vibrio aestuarianus } \\
\text { Prevalence }\end{array}$} \\
\hline & \multirow{2}{*}{\multicolumn{2}{|c|}{$\begin{array}{c}\text { 13-16 June } \\
\text { OsHV-1 }\end{array}$}} & \multirow{3}{*}{$\begin{array}{c}\text { 9-12 September } \\
\text { OsHV-1 } \\
\text { Quantity }\end{array}$} & \\
\hline & & & & \\
\hline & Prevalence & Quantity & & \\
\hline \multicolumn{5}{|c|}{ Outside farming area } \\
\hline 2 & - & - & - & $0 / 6$ \\
\hline 3 & - & - & - & $0 / 6$ \\
\hline 5 & $3 / 10$ & $1.98 \times 10^{4}$ & $2.48 \times 10^{2}$ & $0 / 6$ \\
\hline 9 & - & - & - & $0 / 6$ \\
\hline 10 & $3 / 10$ & $2.98 \times 10^{2}$ & - & $0 / 6$ \\
\hline 16 & $0 / 10$ & 0 & $9.8 \times 10^{1}$ & - \\
\hline 18 & - & - & - & $0 / 6$ \\
\hline 19 & - & - & - & $0 / 6$ \\
\hline 20 & - & - & - & $0 / 6$ \\
\hline 22 & $5 / 10$ & $5.74 \times 10^{3}$ & 0 & $0 / 6$ \\
\hline \multicolumn{5}{|c|}{ Grandcamp farming area } \\
\hline 24 & $10 / 10$ & $6.99 \times 10^{7}$ & $4.94 \times 10^{3}$ & $0 / 6$ \\
\hline 26 & - & - & - & $1 / 6$ \\
\hline 28 & $10 / 10$ & $2.07 \times 10^{5}$ & - & $0 / 6$ \\
\hline 29 & $10 / 10$ & $5.06 \times 10^{4}$ & - & - \\
\hline 31 & $10 / 10$ & $2.96 \times 10^{7}$ & - & - \\
\hline 32 & $10 / 10$ & $3.22 \times 10^{8}$ & - & $0 / 6$ \\
\hline 38 & - & - & - & $1 / 6$ \\
\hline 39 & $9 / 10$ & $3.71 \times 10^{8}$ & $6.08 \times 10^{3}$ & $0 / 6$ \\
\hline \multicolumn{5}{|c|}{ Utah Beach farming area } \\
\hline 34 & $0 / 10$ & 0 & - & $0 / 6$ \\
\hline 35 & $0 / 10$ & 0 & 0 & $0 / 6$ \\
\hline 37 & - & - & - & $0 / 6$ \\
\hline
\end{tabular}


Table 3. Results of uni- and multivariate generalized linear models for each combination of period and age class of oysters. Variables were centred and standardized. Asterisks indicate significance: ${ }^{* * *} \mathrm{p}<0.001,{ }^{* *} \mathrm{p}<0.01,{ }^{*} \mathrm{p}<0.05,{ }^{+} \mathrm{p}<0.1$. AIC: Akaike's information criterion. -: no calculation possible due to data smoothing

\begin{tabular}{|c|c|c|c|c|}
\hline Variable & Estimate & $\mathrm{SE}$ & $\mathrm{p}(>\chi)$ & $\mathrm{AIC}$ \\
\hline \multicolumn{5}{|l|}{ Young oysters - Whole period } \\
\hline \multicolumn{5}{|l|}{ Univariate models } \\
\hline Connectivity Grandcamp farming area (May) & 0.65 & 0.14 & $1.75 \times 10^{-6 * * *}$ & - \\
\hline Chlorophyll a & -0.56 & 0.16 & $2.69 \times 10^{-4 * * *}$ & - \\
\hline Connectivity Utah farming area (May) & -0.41 & 0.24 & $0.06^{+}$ & - \\
\hline Connectivity Carentan Channel (May) & -0.21 & 0.18 & 0.24 & - \\
\hline Connectivity Carentan Channel (February) & -0.20 & 0.19 & 0.27 & - \\
\hline Salinity & 0.15 & 0.19 & 0.42 & - \\
\hline Temperature & -0.08 & 0.17 & 0.63 & - \\
\hline Connectivity Isigny Channel (May) & -0.02 & 0.18 & 0.90 & - \\
\hline Connectivity Isigny Channel (Feb.) & -0.01 & 0.18 & 0.95 & - \\
\hline \multicolumn{5}{|l|}{ Multiple covariates } \\
\hline Connectivity Grandcamp farming area (May) & 0.49 & 0.16 & $1.54 \times 10^{-6 * * *}$ & - \\
\hline Chl a & -0.32 & 0.16 & $0.04^{*}$ & - \\
\hline \multicolumn{5}{|l|}{ Adult oysters - Period 1} \\
\hline \multicolumn{5}{|l|}{ Univariate models } \\
\hline Connectivity Carentan Channel (Feb.) & 0.53 & 0.038 & $<2.2 \times 10^{-16 * * *}$ & 644 \\
\hline Salinity & -0.44 & 0.035 & $<2.2 \times 10^{-16 * * *}$ & 694 \\
\hline Connectivity Carentan Channel (May) & 0.46 & 0.038 & $<2.2 \times 10^{-16 * * *}$ & 700 \\
\hline Temperature & 0.20 & 0.036 & $1.37 \times 10^{-8 * * *}$ & 825 \\
\hline Chl a & 0.18 & 0.038 & $9.18 \times 10^{-7 * * *}$ & 833 \\
\hline Connectivity Isigny Channel (Feb.) & 0.09 & 0.036 & $0.01^{*}$ & 851 \\
\hline Connectivity Utah farming area (May) & 0.06 & 0.035 & $0.08^{+}$ & 854 \\
\hline Connectivity Isigny Channel (May) & 0.06 & 0.037 & 0.11 & 855 \\
\hline Connectivity Grandcamp farming area (May) & -0.01 & 0.036 & 0.89 & 857 \\
\hline \multicolumn{5}{|l|}{ Multiple covariates } \\
\hline Connectivity Carentan Channel (Feb.) & 0.40 & 0.05 & $<2.2 \times 10^{-16 * * *}$ & \\
\hline Salinity & -0.20 & 0.05 & $1.93 \times 10^{-5 * * *}$ & 627 \\
\hline \multicolumn{5}{|l|}{ Adult oysters - Period 2} \\
\hline \multicolumn{5}{|l|}{ Univariate models } \\
\hline Connectivity Grandcamp farming area (August) & 0.58 & 0.05 & $<2.2 \times 10^{-16 * * *}$ & 524 \\
\hline Connectivity Isigny Channel (Aug.) & 0.74 & 0.07 & $<2.2 \times 10^{-16 * * *}$ & 558 \\
\hline Salinity & -0.57 & 0.08 & $2.83 \times 10^{-15 * * *}$ & 610 \\
\hline Connectivity Utah farming area (Aug.) & -0.42 & 0.06 & $4.93 \times 10^{-14 * * *}$ & 616 \\
\hline Connectivity Isigny Channel (Feb.) & 0.45 & 0.07 & $3.4 \times 10^{-11 * * *}$ & 628 \\
\hline Chl a & -0.31 & 0.05 & $3.47 \times 10^{-9 * * *}$ & 637 \\
\hline Connectivity Carentan Channel (Aug.) & 0.30 & 0.06 & $8.4 \times 10^{-8 * * *}$ & 644 \\
\hline Temperature & -0.29 & 0.06 & $4.30 \times 10^{-6 * * *}$ & 651 \\
\hline Connectivity Carentan Channel (Feb.) & -0.19 & 0.06 & $1.3 \times 10^{-3 * *}$ & 662 \\
\hline \multicolumn{5}{|l|}{ Multiple covariates } \\
\hline Connectivity Grandcamp farming area (Aug.) & -0.39 & 0.12 & $<2.2 \times 10^{-16 * * *}$ & \\
\hline Salinity & -2.98 & 0.28 & $2.53 \times 10^{-8 * * *}$ & \\
\hline Connectivity Utah farming area (Aug.) & -0.02 & 0.13 & $1.68 \times 10^{-12 * * *}$ & \\
\hline Connectivity Isigny Channel (Feb.) & 1.13 & 0.18 & $7.31 \times 10^{-6 * * *}$ & \\
\hline $\mathrm{Chl} \mathrm{a}$ & -0.51 & 0.11 & $5.71 \times 10^{-6 * * *}$ & \\
\hline Temperature & 1.19 & 0.15 & $5.52 \times 10^{-3 * *}$ & \\
\hline Connectivity Carentan Channel (Feb.) & -2.12 & 0.25 & $<2.2 \times 10^{-16 * * *}$ & 331 \\
\hline
\end{tabular}

Maps of connectivity and chl a concentration allowed visualization of their spatial links with mortality (Figs. S4 \& S11 in Supplements 2 and 6, respectively).

Predicted maps of adult mortalities were also produced by co-kriging using connectivity to a channel river (Carentan) and salinity for Period 1 and connectivity to the Grandcamp farming area and salinity (i.e. the 2 strongest associated variables) for Period 2 . The fits between prediction and observation were moderate for Period 1 and good for Period $2\left(R^{2}=0.30\right.$ and 


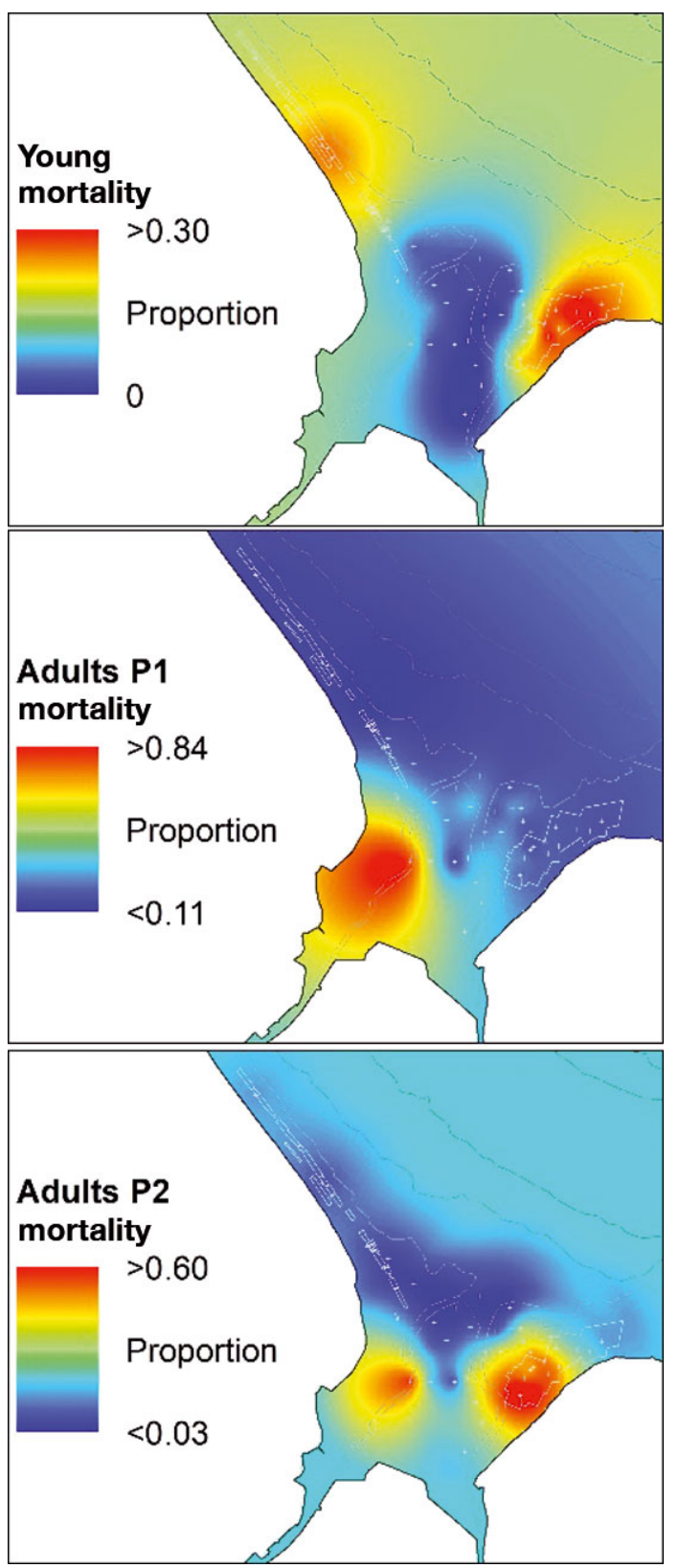

Fig. 4. Co-kriged maps of predicted Pacific oyster mortality (young, and adults during Period 1 and Period 2). Co-kriging variables were: connectivity to the Grandcamp farming area (May) and chlorophyll a for young oysters; connectivity to the Carentan channel (February) and salinity for adults during Period 1 ; and connectivity to the Grandcamp farming area (August) and salinity for adults during Period 2

0.62 respectively, Table 1). For Period 1, an important cluster of mortality was predicted in the southwestern part of the bay, outside the shellfish farming area (Fig. 4) but in an area with very few sampling sites. Sites 2, 5 and 6, located inside or at the border, showed high mortality (Fig. 3c). This mortality matched high values of connectivity to the Carentan channel and low values of salinity (Figs. S4 \& S12). According to observations, mortalities were also predicted to a lesser extent in the southern part of the BdV outside the farming area. This cluster corresponded to intermediate values of salinity.

During Period 2, the highest mortality was predicted in the eastern part of the bay (Fig. 4), in agreement with observations (Fig. 3d) and with a strong correlation with connectivity to the Grandcamp farming area (Fig. S4). Localized mortality observed in the western part (Site 2; Fig. 3d) was also predicted by kriging and associated with a patch of very low salinity (Fig. S13 in Supplement 6).

\section{DISCUSSION}

Mortality of young oysters was associated with the detection of OsHV-1 DNA and occurred in the inshore farming area at the eastern part of the BdV where oyster density is the highest (Gangnery et al. 2015). This suggests that a high oyster density provides suitable conditions for an OsHV-1 outbreak, as previously reported in a Mediterranean lagoon (Pernet et al. 2014a,b) and along an inshore-offshore gradient in Brittany (Pernet et al. 2018). This is consistent with the general principles of population dynamics of infectious diseases (Anderson \& May 1979) that apply to marine organisms (McCallum et al. 2004, Krkošek 2010). However, the transmission model and host density thresholds above which OsHV-1 can spread and be maintained in a host population are still unknown (Pernet et al. 2016).

Mortalities spread $1 \mathrm{~km}$ from the nearest farming area, but OsHV-1 DNA was detected much farther away $(>3 \mathrm{~km})$, suggesting that OsHV-1 particles may be transported over long distances by seawater currents (Pernet et al. 2012, 2014a, 2018). In support of this hypothesis, we found that hydrological connectivity to the Grandcamp farming area obtained from a 3D hydrodynamic model was strongly associated with mortality risk of young oysters.

The variogram range of mortality was $1.7 \mathrm{~km}$, which is consistent with previously reported values for the Mediterranean Thau lagoon $(1.5 \mathrm{~km}$; Pernet et al. 2014 b). Together, these results reveal that sample locations separated by distances lower than 1.5$1.7 \mathrm{~km}$ are spatially autocorrelated, whereas locations farther apart are not. This geostatistical parameter allows identifying space-time clusters of cases and can be used for defining epidemiological units for surveillance, monitoring or management (Peeler \& Taylor 2011). 
Oysters outside the Grandcamp farming area could be infected without exhibiting mortalities. Similarly, subclinical OsHV-1 infections of oysters were reported at offshore sites in Brittany, likely reflecting a dilution effect of viral particles and reduced host density (Pernet et al. 2018). Indeed, biomass of infected oysters and decreasing seawater renewal were associated with higher mortality risk of young oysters in the laboratory (Evans et al. 2015, Petton et al. 2015a), and there is a dose-response relationship between OsHV-1 particle concentration in the seawater and young mortality (Paul-Pont et al. 2015, Petton et al. 2019).

Alternatively, subclinical infection of oysters off the farming area were also associated with better environmental and host conditions (Pernet et al. 2014b, 2018). For instance, lower mortality risk was associated with increased food quantity and quality, growth rate and energy reserves of oysters offshore. It is generally assumed that an immune response is costly, so that food availability likely enhances the immune response and disease resistance of oysters (Sheldon \& Verhulst 1996, Lochmiller \& Deerenberg 2000). In line with this, we found that higher chl a concentration (obtained from a biogeochemical model as a proxy for food availability) outside the farming area was associated with lower mortality risk of young oysters. Also, dry meat mass of young reared outside the farming area was 2.5 times higher than that of young held in the farming areas at the end of the study period (1.12 \pm 0.15 vs. $0.46 \pm 0.15 \mathrm{~g}$, unpublished data).

Mortality risk of young oysters was lowest at Utah Beach, which is used to farm mussels and adult oysters and is located opposite to Grandcamp where young oysters are raised. Similarly, the risk of OsHV1-induced mortality in the Mediterranean Thau lagoon is lower in farming areas dedicated to mussels and adult oysters than in farms dedicated to young oysters (Pernet et al. 2014a). Together, this suggests that the presence of young oysters increases the risk of mortality associated with OsHV-1. However, the contribution of adult oysters and mussels as a source or sink of viral particles needs further investigation.

Mortality of young oysters began when seawater temperature reached $16^{\circ} \mathrm{C}$, confirming that temperature is a triggering risk factor (Pernet et al. 2012, Renault et al. 2014). The spatial variability of seawater temperature was low and was not associated with mortality risk of young oysters. Mean salinity varied from 21.8 to 34.5 within the study area and occasionally decreased to values as low as 5 for several minutes, but this parameter was not associated with mortality risk of young oysters (data repository). This confirms previous laboratory experiments which concluded that reducing disease risk by means of low salinity is unlikely in the field (Fuhrmann et al. 2016).

For adult oysters, the epidemiologic situation was less clear than for young oysters. Indeed, adults were not SPF and showed mortality after thermal elevation in the laboratory, probably associated with endogenous bacterial pathogens (Petton et al. 2015b, Parizadeh et al. 2018). Also, they exhibited 2 temporally distinct episodes of mortality in the field, the first of which occurred just after deployment. Considering the initial health status of these oysters, the first mortality episode may reflect favourable conditions to reveal an infection that was exacerbated by handling stress (Lacoste et al. 2002, Ellis et al. 2011). Finally, the proportion of Vibrio aestuarianus present in adult oysters surviving at the end of the study was low so that we were unable to determine whether it was associated with the mortality. To identify the pathogen(s) that caused the mortality, it would have been necessary to perform more thorough analyses during the mortality episodes, both on live and moribund oysters, but we were limited by the large sampling interval adopted in our study and the low number of live oysters. Despite these biases and uncertainties, determination of mortality risk factors remains interesting because these mortality events are typical of those occurring in the shellfish industry, which relies on movements of oysters with unknown aetiologies (e.g. Brenner et al. 2014).

During the first period, higher connectivity to channel rivers (Carentan) and lower salinity were associated with a higher risk of mortality in adults. High mortalities of adult oysters in the southwestern part of the bay were therefore associated with freshwater inputs from the Carentan channel characterized by lower salinity. These environmental risk factors may have provided favourable conditions for infection.

The fact that freshwater input in estuarine ecosystems was a mortality risk factor for adult oysters confirms previous studies and probably reflects the interactive effect of decreasing salinity and increasing temperature, nutrients and chlorophyll concentration, which induced physiological imbalances of the hosts and increased their susceptibility to pathogens (Samain \& McCombie 2008). Recently, periods of low salinity and high temperature coincided with mass mortalities of unknown aetiology in cultivated Crassostrea gigas in Australia (Go et al. 2017). Although this species is considered to be both 'euryhaline' and 'eurythermal' i.e. it has a wide tolerance to salinity and temperature changes (Bayne 2017), low salinity can induce major physiological changes (e.g. 
Shumway 1977, Fuhrmann et al. 2018), and immune functions are impaired, with direct effects on the viability and activity of haemocytes (Gagnaire et al. 2006). Therefore, decreasing salinity may increase oyster susceptibility to pathogens.

Concomitantly, freshwater inputs probably induce changes in microbial communities living in association with oysters (e.g. Herlemann et al. 2011). For instance, both salinity and temperature affect the occurrence and persistence of bacteria in the aquatic environment (Vezzulli et al. 2015). The optimal salinity for the growth of pathogenic strains of $V$. splendidus and $V$. aestuarianus is approximately 20 , which corresponds to the mean values observed in the southwestern part of the bay where adult mortality occurred.

The risk factors associated with adult mortalities during the second period were partly different from those associated with the first period. Connectivity to the Grandcamp farming area was the main factor associated with mortality risk of adult oysters during the second period, suggesting that proximity to oyster farms provides suitable conditions for mortality outbreaks. This may reflect the transmission process of infectious diseases as previously reported for young oysters.

In our study, mortality of young oysters was similar to those reported by the Ifremer oyster observatory network in Grandcamp and elsewhere in France $(53.8 \pm 9.1 \%$, Fleury et al. 2015). In contrast, mortality of adult oysters was the highest recorded in France and agrees with the oyster observatory network, which reports $43.1 \%$ mortality in 18 mo old oysters and $70.6 \%$ mortality in 30 mo old oysters at Grandcamp (Fleury et al. 2015).

The risk factors involved in adult and young oyster mortalities were partly different, which is consistent with the fact that their origin was not the same. Mortality risk of adult oysters was associated with connectivity to channel rivers and salinity, whereas young oyster mortality was not. Adult mortality was thought to have been caused by pathogenic bacteria, whereas mortality of young oysters was clearly associated with OsHV-1.

However, connectivity with oyster farms is a mortality risk factor that is common to both age groups of oysters. Therefore, disease management strategies that focus on lowering infection in oyster-farming areas, such as regulation of density and movements of oysters, make sense. Particularly in the BdV, where there is no natural recruitment of oysters, effects of OsHV-1 could be reduced by temporarily ceasing restocking and using oysters that are free of OsHV-1 (Murray et al. 2012). This was observed for 4 consecutive years in a small bay area in France where Pacific oysters do not recruit and growers use animals only from nurseries that are free of OsHV-1 (P. Glize pers. comm. cited by Pernet et al. 2016).

$\mathrm{Chl}$ a was associated with lower mortality risk in both young and adult oysters (in Period 2), suggesting that food availability influences disease resistance. Although chl a was not always included in multiple covariates regression models, it is likely a universal risk factor that should be taken into account in disease control measures. In countries that have adopted an ecosystem approach, bivalve farming generally relies on the 'production carrying capacity', which consists of predicting the maximum sustainable yield of cultured bivalves based on the physical carrying capacity and the magnitude of primary production (i.e. oyster food source). In order to mitigate pathogen spread and emergence, bivalve aquaculture should consider density regulations for farmed animals in a way that limits food depletion to a threshold value that promotes growth and energetic status of oysters.

To conclude, this study shows how spatial epidemiology coupled with environmental models allows us to better understand factors that govern the spatial patterns and rates of spread of diseases. This is a promising avenue for identifying and prioritizing disease risk factors. By providing a spatially explicit framework in which disease mortality risk factors are predicted from models (hydrodynamic connectivity, temperature, salinity and chl a concentration), our study offers perspectives for their application in the management of marine diseases.

Acknowledgements. We thank particularly C. Behra, W. Louis, F. Maheux, C. Mary and B. Simon for managing the field work. More generally, we thank all the people who participated in the field work: G. Courtay, C. Etourneau, S. Françoise, F. Guyon, O. Jolly, P.A. Leconte, L. Lamort, E. Le Gagneur, F. Marais, F. Menet-Nédélec, O. Pierre-Duplessix, E. Rabiller, C. Roger and L. Varin. We thank M. Ropert for building GIS maps and L. Dubroca for advice on statistics. Model validation used data provided by the RESCO and RHLN networks supported by the French Ministry for Ecology, Seine-Normandy River Basin Agency, Normandie Region and Ifremer. This work is part of the Gigassat project funded by the French National Research Agency No. ANR-12-AGRO-0001.

\section{LITERATURE CITED}

Anderson RM, May RM (1979) Population biology of infectious diseases: Part I. Nature 280:361-367

Azéma P, Lamy JB, Boudry P, Renault T, Travers MA, Dégremont L (2017) Genetic parameters of resistance to Vibrio aestuarianus, and OsHV-1 infections in the Pacific oyster, 
Crassostrea gigas, at three different life stages. Genet Sel Evol 49:23

Barbosa Solomieu V, Renault T, Travers MA (2015) Mass mortality in bivalves and the intricate case of the Pacific oyster, Crassostrea gigas. J Invertebr Pathol 131:2-10

Bayne BL (2017) Biology of oysters. Developments in aquaculture and fisheries science, Vol 41. Elsevier, London

* Brenner M, Fraser D, Van Nieuwenhove K, O'Beirn F and others (2014) Bivalve aquaculture transfers in Atlantic Europe. Part B: Environmental impacts of transfer activities. Ocean Coast Manag 89:139-146

Bushek D, Ford SE, Burt I (2012) Long-term patterns of an estuarine pathogen along a salinity gradient. J Mar Res 70:225-251

de Kantzow M, Hick P, Becker JA, Whittington RJ (2016) Effect of water temperature on mortality of Pacific oysters Crassostrea gigas associated with microvariant ostreid herpesvirus 1 (OsHV-1 $\mu$ Var). Aquacult Environ Interact 8:419-428

de Lorgeril J, Escoubas JM, Loubiere V, Pernet F and others (2018) Inefficient immune response is associated with microbial permissiveness in juvenile oysters affected by mass mortalities on field. Fish Shellfish Immunol 77: 156-163

* Dégremont L (2011) Evidence of herpesvirus (OsHV-1) resistance in juvenile Crassostrea gigas selected for high resistance to the summer mortality phenomenon. Aquaculture 317:94-98

Dégremont L (2013) Size and genotype affect resistance to mortality caused by OsHV-1 in Crassostrea gigas. Aquaculture 416-417:129-134

* Dégremont L, Garcia C, Allen SK Jr (2015) Genetic improvement for disease resistance in oysters: a review. J Invertebr Pathol 131:226-241

Nelaporte M, Soudant P, Lambert C, Moal J, Pouvreau S, Samain JF (2006) Impact of food availability on energy storage and defense related hemocyte parameters of the Pacific oyster Crassostrea gigas during an experimental reproductive cycle. Aquaculture 254:571-582

* Delisle L, Petton B, Burguin JF, Morga B, Corporeau C, Pernet F (2018) Temperature modulate [sic] disease susceptibility of the Pacific oyster Crassostrea gigas and virulence of the Ostreid herpesvirus type 1. Fish Shellfish Immunol 80:71-79

EFSA AHAW Panel (European Food Safety Authority Panel on Animal Health and Welfare (2015) Scientific opinion on oyster mortality. EFSA J 13:4122

Elliott P, Wartenberg D (2004) Spatial epidemiology: current approaches and future challenges. Environ Health Perspect 112:998-1006

E Ellis RP, Parry H, Spicer JI, Hutchinson TH, Pipe RK, Widdicombe $S$ (2011) Immunological function in marine invertebrates: responses to environmental perturbation. Fish Shellfish Immunol 30:1209-1222

Evans O, Hick P, Dhand N, Whittington RJ (2015) Transmission of Ostreid herpesvirus-1 in Crassostrea gigas by cohabitation: effects of food and number of infected donor oysters. Aquacult Environ Interact 7:281-295

Faraway JJ (2016) Extending the linear model with R: generalized linear, mixed effects and nonparametric regression models, Vol 124. CRC Press, Boca Raton, FL

Fleury E, D'Amico F, Bouget JF, Chabirand JM and others (2015) RESCO Réseau d'Observations Conchylicoles. Rapport annuel campagne 2014, https://archimer.ifremer.fr /doc/00287/39794

Fuhrmann M, Petton B, Quillien V, Faury N, Morga B, Pernet F (2016) Salinity influences disease-induced mortal- ity of the oyster Crassostrea gigas and infectivity of the ostreid herpesvirus 1 (OsHV-1). Aquacult Environ Interact 8:543-552

F Fuhrmann M, Delisle L, Petton B, Corporeau C, Pernet F (2018) Metabolism of the Pacific oyster, Crassostrea gigas, is influenced by salinity and modulates survival to the Ostreid herpesvirus OsHV-1. Biol Open 7:bio028134

Fuhrmann M, Richard G, Quere C, Petton B, Pernet F (2019) Low $\mathrm{pH}$ reduced survival of the oyster Crassostrea gigas exposed to the Ostreid herpesvirus 1 by altering the metabolic response of the host. Aquaculture 503: 167-174

KGagnaire B, Frouin H, Moreau K, Thomas-Guyon H, Renault $\mathrm{T}$ (2006) Effects of temperature and salinity on haemocyte activities of the Pacific oyster, Crassostrea gigas (Thunberg). Fish Shellfish Immunol 20:536-547

Gangnery A, Cugier P, Le Gendre R, Legendre A and others (2015) Projet OGIVE. Outils d'aide à la gestion et à la valorisation des ecosystèmes conchylicoles de Basse-Normandie. Rapport final de contrat de phase III (2011-2013) 15-02, https://archimer.ifremer.fr/doc/00253/36468

* Go J, Deutscher AT, Spiers ZB, Dahle K, Kirkland PD, Jenkins C (2017) Mass mortalities of unknown aetiology in Pacific oysters Crassostrea gigas in Port Stephens, New South Wales, Australia. Dis Aquat Org 125:227-242

Goudenège D, Travers MA, Lemire A, Petton B and others (2015) A single regulatory gene is sufficient to alter Vibrio aestuarianus pathogenicity in oysters. Environ Microbiol 17:4189-4199

* Grangeré K, Ménesguen A, Lefebvre S, Bacher C, Pouvreau S (2009) Modelling the influence of environmental factors on the physiological status of the Pacific oyster Crassostrea gigas in an estuarine embayment; the Baie des Veys (France). J Sea Res 62:147-158

Grangeré K, Lefebvre S, Bacher C, Cugier P, Ménesguen A (2010) Modelling the spatial heterogeneity of ecological processes in an intertidal estuarine bay: dynamic interactions between bivalves and phytoplankton. Mar Ecol Prog Ser 415:141-158

*Herlemann DPR, Labrenz $M$, Jürgens $K$, Bertilsson $S$, Waniek JJ, Andersson AF (2011) Transitions in bacterial communities along the $2000 \mathrm{~km}$ salinity gradient of the Baltic Sea. ISME J 5:1571

* Hick PM, Evans O, Rubio A, Dhand NK, Whittington RJ (2018) Both age and size influence susceptibility of Pacific oysters (Crassostrea gigas) to disease caused by Ostreid herpesvirus-1 (OsHV-1) in replicated field and laboratory experiments. Aquaculture 489:110-120

Krkošek M (2010) Host density thresholds and disease control for fisheries and aquaculture. Aquacult Environ Interact 1:21-32

KLacoste A, Malham SK, Gélébart F, Cueff A, Poulet SA (2002) Stress-induced immune changes in the oyster Crassostrea gigas. Dev Comp Immunol 26:1-9

* Lazure P, Dumas F (2008) An external-internal mode coupling for a 3D hydrodynamical model for applications at regional scale (MARS). Adv Water Resour 31:233-250

* Le Roux F, Wegner KM, Polz MF (2016) Oysters and vibrios as a model for disease dynamics in wild animals. Trends Microbiol 24:568-580

Legendre P, Legendre L (1998) Numerical ecology, Vol 20. Elsevier, Amsterdam

* Lemire A, Goudenège D, Versigny T, Petton B, Calteau A, Labreuche Y, Le Roux F (2015) Populations, not clones, are the unit of vibrio pathogenesis in naturally infected oysters. ISME J 9:1523-1531

Lochmiller RL, Deerenberg C (2000) Trade-offs in evolution- 
ary immunology: Just what is the cost of immunity? Oikos 88:87-98

Martenot C, Oden E, Travaillé E, Malas JP, Houssin M (2010) Comparison of two real-time PCR methods for detection of ostreid herpesvirus 1 in the Pacific oyster Crassostrea gigas. J Virol Methods 170:86-89

*McBratney AB, Webster R (1986) Choosing functions for semi-variograms of soil properties and fitting them to sampling estimates. J Soil Sci 37:617-639

McCallum HI, Kuris A, Harvell CD, Lafferty KD, Smith GW, Porter J (2004) Does terrestrial epidemiology apply to marine systems? Trends Ecol Evol 19:585-591

* Ménesguen A, Dussauze M, Dumas F, Thouvenin B, Garnier V, Lecornu F, Répécaud M (2019) Ecological model of the Bay of Biscay and English Channel shelf for environmental status assessment. I. Nutrients, phytoplankton and oxygen. Ocean Model 133:56-78

* Murray AG, Marcos-Lopez M, Collet B, Munro LA (2012) A review of the risk posed to Scottish mollusc aquaculture from Bonamia, Marteilia and oyster herpesvirus. Aquaculture 370-371:7-13

Ostfeld RS, Glass GE, Keesing F (2005) Spatial epidemiology: an emerging (or re-emerging) discipline. Trends Ecol Evol 20:328-336

Parizadeh L, Tourbiez D, Garcia C, Haffner P, Dégremont L, Le Roux F, Travers MA (2018) Ecologically realistic model of infection for exploring the host damage caused by Vibrio aestuarianus. Environ Microbiol 20:4343-4355

Passy P, Le Gendre R, Garnier J, Cugier P and others (2016) Eutrophication modelling chain for improved management strategies to prevent algal blooms in the Bay of Seine. Mar Ecol Prog Ser 543:107-125

* Paul-Pont I, Dhand NK, Whittington RJ (2013) Influence of husbandry practices on OsHV-1 associated mortality of Pacific oysters Crassostrea gigas. Aquaculture 412-413: 202-214

Paul-Pont I, Evans O, Dhand NK, Whittington RJ (2015) Experimental infections of Pacific oyster Crassostrea gigas using the Australian ostreid herpesvirus-1 (OsHV-1) $\mu$ Var strain. Dis Aquat Org 113:137-147

Peeler EJ, Taylor NGH (2011) The application of epidemiology in aquatic animal health -opportunities and challenges. Vet Res 42:94

Pernet F, Barret J, Le Gall P, Corporeau C and others (2012) Mass mortalities of Pacific oysters Crassostrea gigas reflect infectious diseases and vary with farming practices in the Thau lagoon, France. Aquacult Environ Interact 2:215-237

Pernet F, Lagarde F, Le Gall P, D'Orbcastel ER (2014a) Associations between farming practices and disease mortality of Pacific oyster Crassostrea gigas in a Mediterranean lagoon. Aquacult Environ Interact 5:99-106

Pernet F, Lagarde F, Jeannée N, Daigle G and others (2014b) Spatial and temporal dynamics of mass mortalities in oysters is influenced by energetic reserves and food quality. PLOS ONE 9:e88469

Pernet F, Tamayo D, Petton B (2015) Influence of low temperatures on the survival of the Pacific oyster (Crassostrea gigas) infected with ostreid herpes virus type 1. Aquaculture 445:57-62

Pernet F, Lupo C, Bacher C, Whittington RJ (2016) Infectious diseases in oyster aquaculture require a new integrated approach. Philos Trans R Soc B 371:20150213

Pernet F, Fuhrmann M, Petton B, Mazurié J and others (2018) Determination of risk factors for herpesvirus outbreak in oysters using a broad-scale spatial epidemiology framework. Sci Rep 8:10869
Petton B, Pernet F, Robert R, Boudry P (2013) Temperature influence on pathogen transmission and subsequent mortalities in juvenile Pacific oysters Crassostrea gigas. Aquacult Environ Interact 3:257-273

* Petton B, Boudry P, Alunno-Bruscia M, Pernet F (2015a) Factors influencing disease-induced mortality of Pacific oysters Crassostrea gigas. Aquacult Environ Interact 6: 205-222

* Petton B, Bruto M, James A, Labreuche Y, Alunno Bruscia M, Le Roux F (2015b) Crassostrea gigas mortality in France: the usual suspect, a herpes virus, may not be the killer in this polymicrobial opportunistic disease. Front Microbiol 6:686

พ Petton B, de Lorgeril J, Mitta G, Daigle G, Pernet F, Alunno Bruscia M (2019) Fine-scale temporal dynamics of herpes virus and vibrios in seawater during a polymicrobial infection in the Pacific oyster Crassostrea gigas. Dis Aquat Org 135:97-106

R Core Team (2018) R: a language and environment for statistical computing. R Foundation for Statistical Computing, Vienna

* Renault T, Bouquet AL, Maurice JT, Lupo C, Blachier P (2014) Ostreid herpesvirus 1 infection among Pacific oyster (Crassostrea gigas) spat: relevance of water temperature to virus replication and circulation prior to the onset of mortality. Appl Environ Microbiol 80: 5419-5426

Koyer J, Ropert M, Costil K (2007) Spatio-temporal changes in mortality, growth and condition of the Pacific oyster, Crassostrea gigas, in Normandy (France). J Shellfish Res 26:973-984

Samain JF, McCombie H (eds) (2008) Summer mortality of Pacific oyster Crassostrea gigas. The Morest project. Editions Quae, Versailles

* Saulnier D, De Decker S, Tourbiez D, Travers MA (2017) Development of a duplex Taqman real-time PCR assay for rapid identification of Vibrio splendidus-related and $V$. aestuarianus strains from bacterial cultures. J Microbiol Methods 140:67-69

* Sheldon BC, Verhulst S (1996) Ecological immunology: costly parasite defences and trade-offs in evolutionary ecology. Trends Ecol Evol 11:317-321

Shumway SE (1977) Effect of salinity fluctuation on the osmotic pressure and $\mathrm{Na}^{+}, \mathrm{Ca}^{2+}$ and $\mathrm{Mg}^{2+}$ ion concentrations in the hemolymph of bivalve molluscs. Mar Biol 41: 153-177

Koletchnik P, Ropert M, Mazurie J, Fleury PG, Le Coz F (2007) Relationships between oyster mortality patterns and environmental data from monitoring databases along the coasts of France. Aquaculture 271:384-400

*Tamayo D, Corporeau C, Petton B, Quere C, Pernet F (2014) Physiological changes in Pacific oyster Crassostrea gigas exposed to the herpesvirus OsHV-1 $\mu$ Var. Aquaculture 432:304-310

พ Thomas Y, Cassou C, Gernez P, Pouvreau S (2018) Oysters as sentinels of climate variability and climate change in coastal ecosystems. Environ Res Lett 13:104009

* Ubertini M, Lefebvre S, Gangnery A, Grangeré K, Le Gendre R, Orvain F (2012) Spatial variability of benthicpelagic coupling in an estuary ecosystem: consequences for microphytobenthos resuspension phenomenon. PLOS ONE 7:e44155

*Vezzulli L, Pezzati E, Stauder M, Stagnaro L, Venier P, Pruzzo C (2015) Aquatic ecology of the oyster pathogens Vibrio splendidus and Vibrio aestuarianus. Environ Microbiol 17:1065-1080

Submitted: February 8, 2019; Accepted: July 11, 2019

Proofs received from author(s): September 10, 2019 